\title{
Alternaria Inhibits Double-Stranded RNA-Induced Cytokine Production through Toll-Like Receptor 3
}

\author{
Kota Wada ${ }^{a, c}$ Takao Kobayashic ${ }^{c}$ Yoshinori Matsuwaki ${ }^{b, c}$ Hiroshi Moriyama ${ }^{b}$ \\ Hirohito Kita ${ }^{c}$ \\ ${ }^{a}$ Department of Otorhinolaryngology, Toho University, and bepartment of Otorhinolaryngology, \\ The Jikei University School of Medicine, Tokyo, Japan; ' Departments of Immunology and Medicine, \\ Mayo Clinic, Rochester, Minn., USA
}

\section{Key Words}

Alternaria - Polyinosinic-polycytidylic acid - Dendritic cells .

Toll-like receptor 3 expression $\cdot$ Host innate immunity

\begin{abstract}
Background: Fungi may be involved in asthma and chronic rhinosinusitis (CRS). Peripheral blood mononuclear cells from CRS patients produce interleukin (IL)-5, IL-13 and interferon (IFN)- $\gamma$ in the presence of Alternaria. In addition, Alternaria produces potent Th2-like adjuvant effects in the airway. Therefore, we hypothesized that Alternaria may inhibit Th1-type defense mechanisms against virus infection. Methods: Dendritic cells (DCs) were generated from mouse bone marrow. The functional responses were assessed by expression of cell surface molecules by FACS (MHC class II, CD40, CD80, CD86 and OX40L). Production of IL-6, chemokine CXCL10 (IP-10), chemokine CXCL11 (I-TAC) and IFN- $\beta$ was measured by ELISA. Toll-like receptor 3 (TLR3) mRNA and protein expression was detected by quantitative real-time PCR and Western blot. Results: Alternaria and polyinosinicpolycytidylic acid (poly I:C) enhanced cell surface expression of MHC class II, CD40, CD80, CD86 and OX40L, and IL-6 production in a concentration-dependent manner. However, Alternaria significantly inhibited production of IP-10, I-TAC and
\end{abstract}

IFN- $\beta$, induced by viral double-stranded RNA (dsRNA) mimic poly I:C. TLR3 mRNA expression and protein production by poly I:C were significantly inhibited by Alternaria. These reactions are likely caused by heat-stable factor(s) in Alternaria extract with $>100 \mathrm{kDa}$ molecular mass. Conclusion: These findings suggest that the fungus Alternaria may inhibit production of IFN- $\beta$ and other cytokines by DCs by suppressing TLR3 expression. These results indicate that Alternaria may inhibit host innate immunity against virus infection.

Copyright $\odot 2013$ S. Karger AG, Basel

\section{Introduction}

The prevalence of asthma has markedly increased over the past 3 decades [1]. The etiology of asthma is not fully understood. It is considered that gene-environmental interactions likely play a pivotal role. Specifically, asthma may represent the exaggerated immune responses to chitin-containing organisms, including house-dust mite, cockroaches and fungi [2-4]. Among various environmental stimuli, an association between fungal exposure and asthma has been clinically and epidemiologically recognized [5]. In particular, exposure to Alternaria, which is ubiquitous both outdoors and indoors [6], is one of the

\section{KARGER}

E-Mail karger@karger.com

www.karger.com/iaa
(C) 2013 S. Karger AG, Basel

1018-2438/13/1616-0075\$38.00/0
Correspondence to: Dr. Kota Wada

Department of Otorhinolaryngology, Toho University

6-11-1 Omori-Nishi, Ota-ku

Tokyo 143-8541 (Japan)

E-Mail wadakota@med.toho-u.ac.jp 
major risk factors for developing asthma $[7,8]$. Viral infection is also associated with acute exacerbations of asthma. Respiratory tract viruses have emerged as the most frequent triggers for exacerbations in both children and adults $[9,10]$. However, the immunological mechanisms underlying these medical problems are poorly understood. In adults who are sensitized to allergens, exposure to sensitizing allergens and respiratory tract viral infection acted in a synergistic manner to significantly increase the risk of hospitalization for acute asthma [11].

Chronic rhinosinusitis (CRS) is a common chronic disease. CRS has been defined by the Task Force of the American Academy of Otolaryngology-Head Neck Surgery based on clinical symptoms and clinical diagnostic criteria [12]. It is treated by medication [13] and endoscopic sinus surgery [14]. Its pathogenesis and etiology are not fully understood. An association between fungi and chronic eosinophilic airway inflammation has been described in patients with severe asthma and certain types of CRS, such as allergic fungal rhinosinusitis [15]. It is frequently refractory to treatment. CRS patients, particularly those with bronchial asthma or with aspirin-induced asthma, sometimes require long-term treatment with corticosteroids and repeated sinus surgery. CRS patients often experience development or worsening of their symptoms after a viral infection [16]. Viral infection has also been shown to cause obstruction of the sinus ostia [17], production of inflammatory mediators by nasal epithelial cells [18] and damage to epithelial cells and cilia [19].

Viruses and viral components are recognized by Tolllike receptors (TLRs), mainly by endosomally located TLR3, TLR7 and TLR8. TLR3 detects double-stranded RNA (dsRNA), which appears during viral replication processes and is expressed in the placenta, pancreas, lung, liver and heart [20], and especially in myeloid dendritic cells (DCs) and epithelial cells [21]. Induction of immune responses by respiratory viruses involves TLR as well as the RNA helicases RIG-I and MDA-5 [22, 23]. Both TLR3 and RNA helicases recognize dsRNA produced during viral infections as well as polyinosinic-polycytidylic acid (poly I:C), a synthetic ligand mimicking viral dsRNA [24-28]. TLR3 induces type I interferon (IFN) responses by activating IFN regulatory factor (IRF) family, IRF-3. Importantly, even low levels of autocrine or paracrine IFN trigger amplification of the antiviral response [29, 30]. IFN- $\beta$ is detected by IFN receptor and forms IFNstimulated gene factor, which translocates to the nucleus and induces the transcription of effector molecules. These effector molecules directly influence protein synthesis such as that of chemokines CXCL10 (IP-10) and CXCL11 (I-TAC).

In this study, we examined the effects of fungal products on innate immunity, in particular antiviral immunity produced by DCs. We found that production of IFN- $\beta$ and chemokines by DCs stimulated with viral RNA was profoundly inhibited by product(s) of fungus, Alternaria. These observations may explain diminished antiviral immunity in patients with asthma or CRS.

\section{Materials and Methods}

Mice

BALB/CJ mice were from Jackson Laboratory (Bar Harbor, Me., USA). All mice were 7- to 9-week-old females. The procedures and the handling of those mice had been reviewed and approved by the Mayo Institutional Animal Care and Use Committee, Mayo Clinic, Rochester, Minn., USA.

\section{Alternaria Extract}

Alternaria alternata culture filtrate fungal extract was from Greer Laboratories (Lenoir, N.C., USA). This extract was derived from media in which A. alternata was grown. The culture filtrate was concentrated, dialyzed and lyophilized.

Generation and Stimulation of Mouse Bone Marrow-Derived

DCs

DCs were generated from mouse bone marrow (BM) using an established protocol [31] with minor modifications [32]. Briefly, mouse BM was obtained from the long bones of the hind legs. After erythrocyte lysis, BM cells were suspended at $1 \times 10^{6} / \mathrm{ml}$ in RPMI 1640 with $10 \%$ FBS, $10 \mathrm{ng} / \mathrm{ml}$ murine GM-CSF and $1 \mathrm{ng} / \mathrm{ml}$ murine interleukin (IL)-4. Cells were plated into wells of 6 -well tissue culture plates and cultured for 6 days; the purity of CD11c + DCs was about $85 \%$. Day 6 DCs were stimulated for $24-48$ h with Alternaria extract $(25-50 \mu \mathrm{g} / \mathrm{ml})$ or poly I:C $(25 \mu \mathrm{g} / \mathrm{ml})$ or combinations thereof. In separate experiments, we further purified DCs with a magnetic cell separation system (MACS; Miltenyi Biotech, Auburn, Calif., USA) and anti-CD11c (N418) immunomagnetic beads (Miltenyi Biotec). These highly purified DCs ( $>97 \%$ purity) behaved similarly to those without MACS purification. We used BM-derived DCs without MACS purification in this study because these extra manipulations might have affected DC functions. The functional responses of DCs to Alternaria extract and poly I:C were assessed by expression of cell surface molecules by FACS, quantitative real-time PCR and Western blotting. Cytokine production was analyzed by ELISA. For FACS analysis, after stimulation for $24 \mathrm{~h}$ (MHC class II, CD40, CD80 and CD86) or $48 \mathrm{~h}$ (OX40L), DCs were preincubated with Fc-receptor blockers (anti$\mathrm{CD} 16 / \mathrm{CD} 32)$ for $30 \mathrm{~min}$ at $4^{\circ} \mathrm{C}$ and stained with PE-conjugated anti-CD11c (clone HL3) and FITC-conjugated anti-MHC class II I-Ad (AMS-32.1), anti-CD40 (HM40-3), anti-CD80 (16-10A1) and anti-CD86 (GL1) or biotinylated anti-OX40L (RM134L) plus FITC-conjugated streptavidin for $30 \mathrm{~min}$ at $4^{\circ} \mathrm{C}$. FITC-conjugated mouse immunoglobulin G 2b (IgG2b), Armenian hamster IgG2, rat IgG2a and rat IgG2a and biotinylated Armenian hamster IgM were used as isotype controls. All Abs used for DC FACS analysis DOI: $10.1159 / 000350365$
Wada/Kobayashi/Matsuwaki/Moriyama/ Kita 
were obtained from BD Pharmingen. After washing, DCs were resuspended in PBS containing $1 \%$ BSA and $0.1 \% \mathrm{NaN} 3$, fixed with $1 \%$ paraformaldehyde and analyzed by a FACScan flow cytometer (BD Immunocytometry Systems, Mountain View, Calif., USA) by gating on a CD11c-positive forward-scatter high population. For cytokine analysis, cell-free supernatants were collected after $24 \mathrm{~h}$ stimulation; concentrations of IL-6, IP-10, I-TAC and IFN- $\beta$ were measured by ELISA kits (R\&D Systems) according to the manufacturer's directions.

\section{Quantitative Real-Time PCR}

Total RNA was isolated from DCs using RNeasy Mini Kit (Qiagen, Valencia, Calif., USA). The RNA was then transcribed into cDNA using Superscript II (Invitrogen, Grand Island, N.Y., USA). Quantitative real-time PCR was performed using SYBR Green PCR Master Mix (Applied Biosystems, Foster City, Calif., USA), according to the manufacturer's instructions. Mouse TLR3 mRNA transcripts were quantified by quantitative real-time PCR with TaqMan Gene Expression Array primer-probe sets (Applied Biosystems) and iCycler with iQ5 Real-Time PCR Detection System (Bio-Rad Laboratories). Transcription was normalized to the $18 \mathrm{~S}$ rRNA transcription in each sample.

\section{Western Blot}

DCs were lysed with Nupage sample buffer (Invitrogen). Samples were boiled for $10 \mathrm{~min}$ and clarified by centrifugation at $3,000 \mathrm{~g}$ at $4^{\circ} \mathrm{C}$ for $15 \mathrm{~min}$ with a microcentrifuge. Ten micrograms of cell lysate per lane was applied to SDS-PAGE and transferred electrically onto polyvinylidene difluoride transfer membranes. The membranes were blocked with PBS containing $0.1 \%$ Tween-20 and 5\% skim milk, probed with the anti-TLR3 antibodies, and visualized with an enhanced chemiluminescence system (Amersham, Piscataway, N.J., USA). Densitometric analysis was carried out with National Institutes of Health image software. The increased densities were compared with the density of samples preincubated with medium alone; they are reported as ratios.

\section{Statistical Analysis}

Data are presented as means $( \pm$ SEM). One-way repeated-measures ANOVA was used to assess significant differences, with post hoc analysis using the Dunnett or Tukey tests. Differences were considered statistically significant at $\mathrm{p}<0.05$.

\section{Results}

Alternaria and poly I:C Induce IL-6 Production and Enhance Expression of Costimulatory Molecules and MHC Class II by DCs

To investigate the effects of Alternaria extract and poly I:C, we examined IL- 6 production and expression of cell surface molecules. DCs $\left(1 \times 10^{6}\right.$ cells $)$ were incubated with Alternaria (0, 25 and $50 \mu \mathrm{g} / \mathrm{ml})$ and poly I:C ( 0 and $25 \mu \mathrm{g} / \mathrm{ml}$ ) for 24 or $48 \mathrm{~h}$. Alternaria extract induced BMderived DCs to produce and release IL-6 in a dose-dependent manner (fig. 1). IL-6 production was also induced by poly I:C alone. There were no additive or synergistic ef-

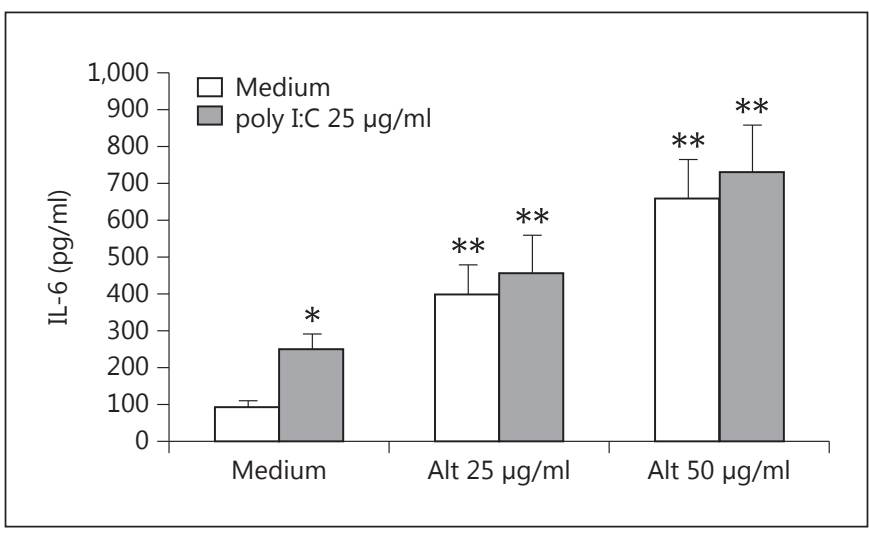

Fig. 1. Alternaria and poly I:C produced IL-6 in a dose-dependent manner. Mouse BM-derived DCs were incubated with different concentrations of Alternaria $(0-50 \mu \mathrm{g} / \mathrm{ml})$ and poly I:C $(0-25 \mu \mathrm{g} /$ $\mathrm{ml}$ ) or medium alone at $37^{\circ} \mathrm{C}$. To monitor IL- 6 production after $24 \mathrm{~h}$, the cell-free supernatants were measured by ELISA. Results show the means \pm SEM from 5 different samples. Alt $=$ Alternaria . ${ }^{*} \mathrm{p}<0.05$ and ${ }^{* *} \mathrm{p}<0.01$ were significant differences compared with medium alone.

fects of Alternaria and poly I:C when they were added together to DCs. In addition, Alternaria increased the expression of MHC class II, CD40, CD80 as well as OX40L, a costimulatory molecule implicated in Th2 development (fig. 2). No apparent effects were observed when poly I:C was added to DCs cultured with Alternaria extract. These findings suggest that Alternaria induces IL-6 production and enhances the expression of MHC class II and costimulatory molecules by DCs.

\section{Alternaria Inhibits IP-10, I-TAC and IFN- $\beta$}

Production by Stimulation of poly I:C

To investigate the effects of Alternaria on antiviral innate immune responses, we examined IP-10, I-TAC and IFN- $\beta$ production by DCs; these chemokines and cytokine suppress viral proliferation and growth. IP-10, ITAC and IFN- $\beta$ production from DCs was significantly induced by poly I:C (fig. 3). Alternaria did not induce IP10 production, but it did induce small amounts of I-TAC and IFN- $\beta$. However, when Alternaria was added to DCs, IP-10 production by poly I:C was completely inhibited (fig. 3a). Furthermore, I-TAC and IFN- $\beta$ production by DCs stimulated with poly I:C was significantly inhibited by Alternaria in a concentration-dependent manner (fig. 3b, c). These findings suggest that, while Alternaria showed minimal effects to induce the production of IP10 , I-TAC and IFN- $\beta$, it inhibits production of these cytokines by DCs stimulated with poly I:C. 

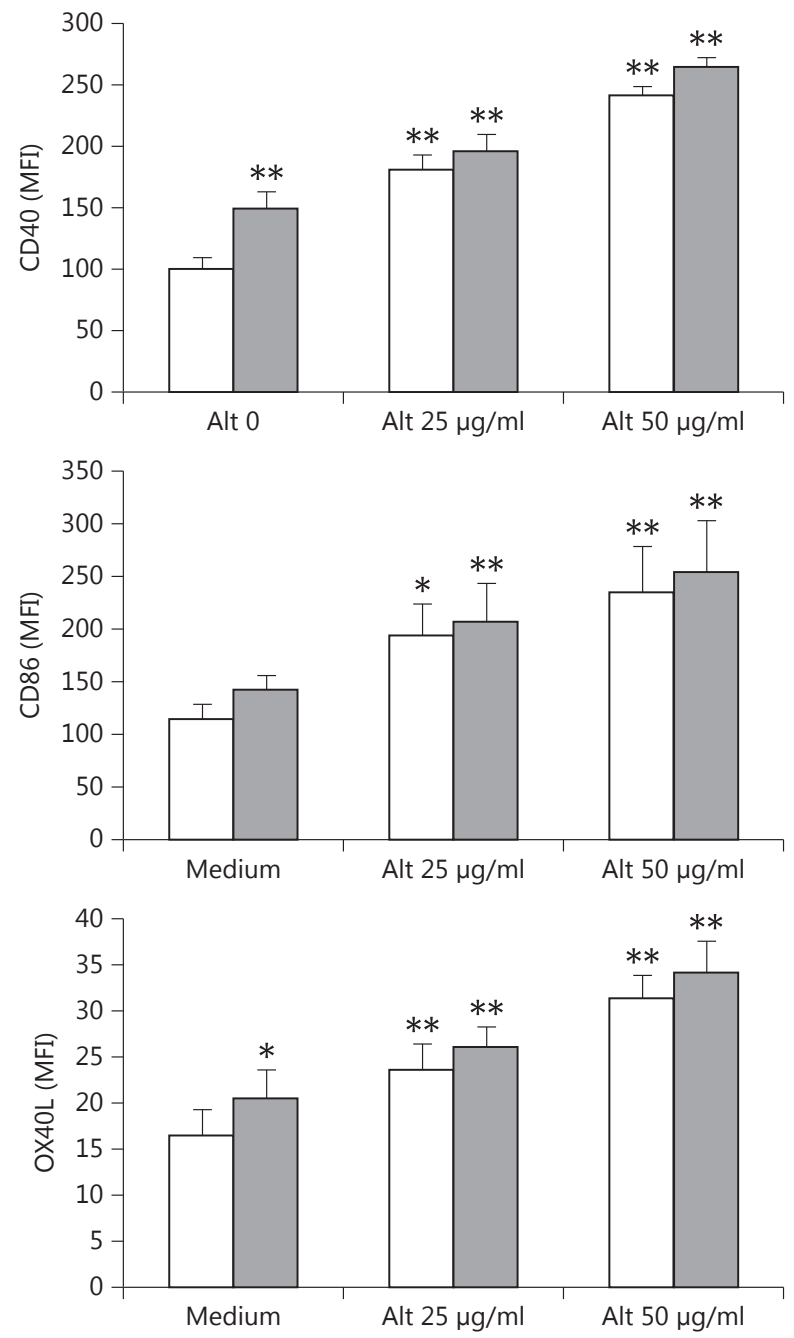
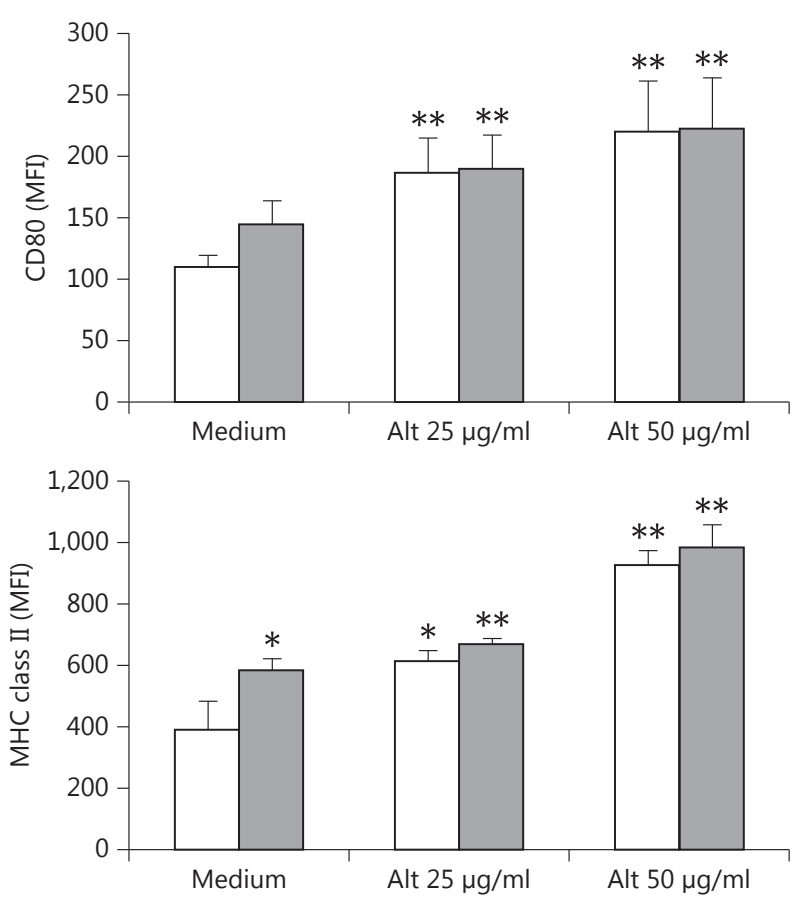

Medium

poly I:C $25 \mu \mathrm{g} / \mathrm{ml}$
Fig. 2. Alternaria and poly I:C enhance expression of MHC class II and costimulatory molecules by DCs. DCs were incubated with medium alone, Alternaria extract $(0-50 \mu \mathrm{g} / \mathrm{ml})$ and poly I:C $(0-25$ $\mu \mathrm{g} / \mathrm{ml})$ for $24 \mathrm{~h}$ (MHC class II, CD40, CD80 and CD86) or $48 \mathrm{~h}$ (OX40L). The expression of MHC class II and costimulatory mol-

Alternaria Inhibits Expression of TLR3 of DCs

To investigate the mechanisms involved in the inhibitory effects of Alternaria, we examined the expression of TLR3. Quantitative real-time PCR analysis showed that TLR3 mRNA expression by DCs was significantly enhanced by poly I:C. In contrast, Alternaria did not induce TLR3 mRNA expression. However, when DCs were cocultured with Alternaria and poly I:C, TLR3 mRNA was significantly inhibited compared to DC stimulation by ecules was analyzed by FACS. Mean expression levels are shown from 3 (MHC class II and OX40L) and 4 (CD40, CD80 and CD86) independent experiments (mean \pm SEM). ${ }^{*} \mathrm{p}<0.05$ and ${ }^{* *} \mathrm{p}<0.01$ compared with medium alone. Alt $=$ Alternaria $; \mathrm{MFI}=$ mean fluorescence intensity. poly I:C alone (fig. 4a). By Western blot, poly I:C increased TLR3 protein expression, but Alternaria did not. Furthermore, similarly to mRNA examinations, Alternaria inhibited poly I:C-induced TLR3 protein expression (fig. $4 \mathrm{~b}$ ). These results were confirmed by densitometric analysis (fig. 4c); data were normalized to the values of medium alone as $100 \%$. Thus, Alternaria likely inhibits TLR 3 expression by DCs stimulated with poly I:C by suppressing mRNA expression. 


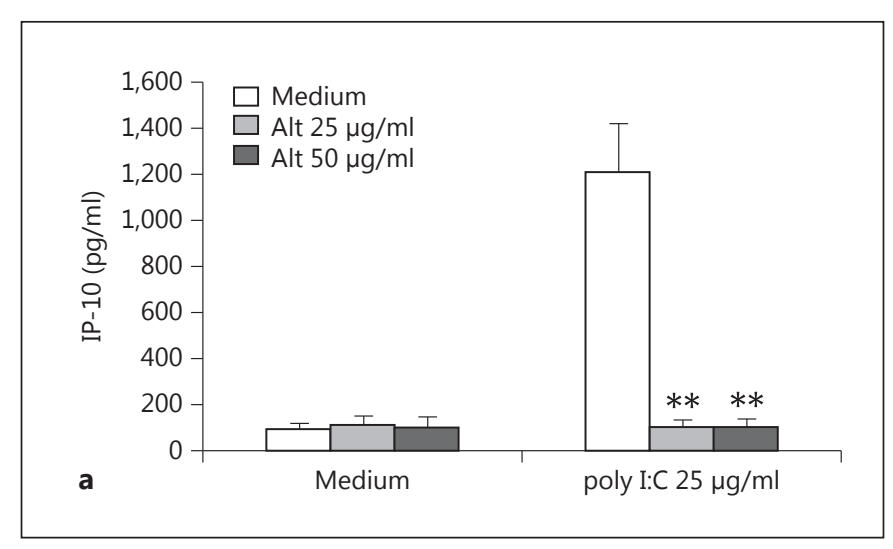

Fig. 3. Alternaria inhibits IP-10, I-TAC and IFN- $\beta$ production by stimulation of poly I:C. DCs were incubated with medium alone, Alternaria extract $(0-50 \mu \mathrm{g} / \mathrm{ml})$ and poly I:C $(0-25 \mu \mathrm{g} / \mathrm{ml})$ for $24 \mathrm{~h}$. IP-10, I-TAC and IFN- $\beta$ levels in the supernatants were measured by ELISA. Results are mean \pm SEM $(n=5) .{ }^{*} \mathrm{p}<0.05$ and ${ }^{* *} \mathrm{p}<0.01$ compared with medium or poly $\mathrm{I}: \mathrm{C}$ alone. Alt $=$ Alternaria.

\section{Characterization of the Inhibitory Factors in Alternaria Extracts}

To characterize the molecules in Alternaria extract that are involved in the inhibitory effect on DCs, we performed a series of experiments. First, we investigated molecular weight $(\mathrm{MW})$. Alternaria extract was subjected to membrane filtration with YM100 Centricom membrane (100-kDa cutoff; Millipore). Second, we investigated the effects of heat treatment. Alternaria extracts were exposed to 4,37 and $56^{\circ} \mathrm{C}$ for $30 \mathrm{~min}$. The ability of Alternaria extract to stimulate IL- 6 production was not affected by treatment at 4 or $37^{\circ} \mathrm{C}$; however, it was significantly inhibited by treatment at $56^{\circ} \mathrm{C}$ (fig. 5a). Furthermore, the stimulatory activity was mainly present in the fraction $>100 \mathrm{kDa}$. The fraction at $<100 \mathrm{kDa}$ slightly inhibited IL-6 production; however, the effect of poly I:C to stimulate IL-6 production was not apparently affected by Alternaria specimens. In contrast, the capacity of Alternaria to inhibit IP-10 production was not affected by treating the extracts at 4,37 or $56^{\circ} \mathrm{C}$ (fig. 5b). Furthermore, the inhibitory activity was mainly present at the fraction with $>100 \mathrm{Da} \mathrm{MW}$, although the fraction at $<100 \mathrm{kDa}$ slightly

Alternaria Inhibits dsRNA-Induced Cytokine Production through TLR3
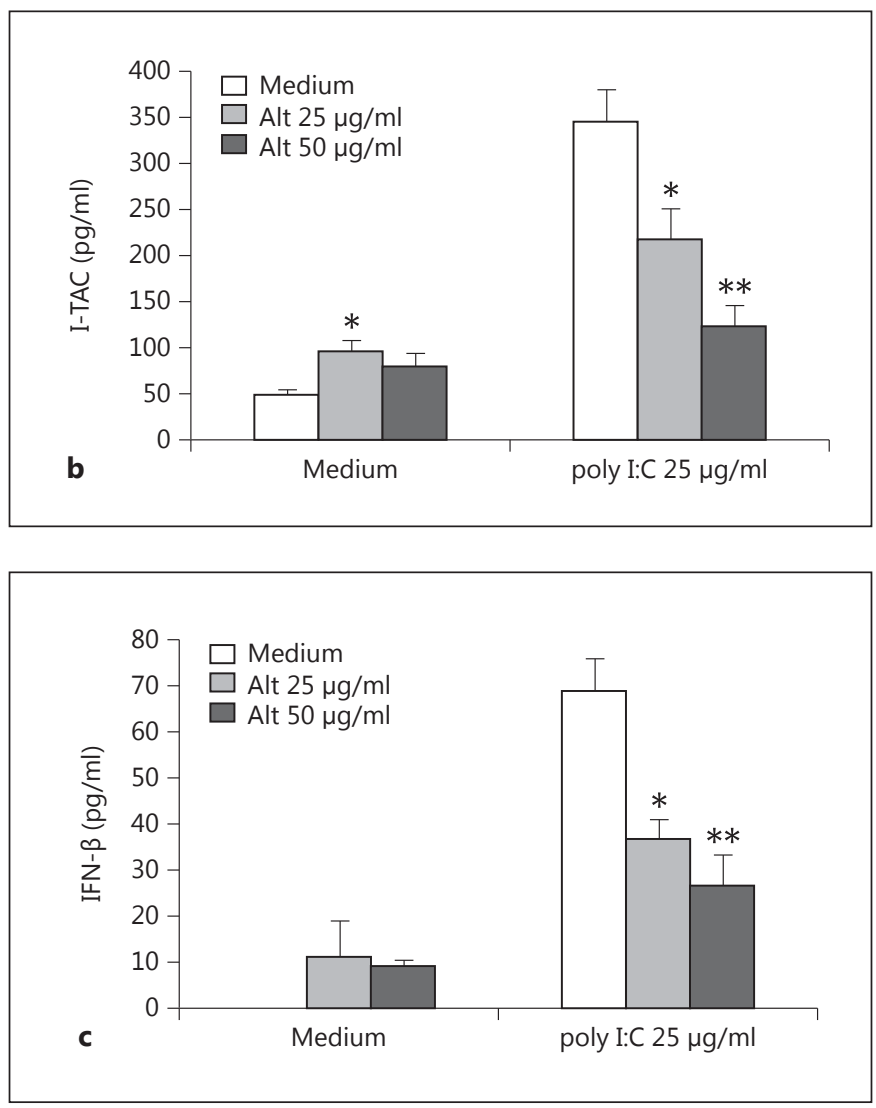

inhibited IP-10 production. These findings suggest that the Alternaria factor(s) that inhibits poly I:C-induced IP10 production by DCs is largely heat-stable and has a molecular mass of $>100 \mathrm{kDa}$.

\section{Discussion}

We used mouse DCs for our research. DCs play a critical role in vertebrate immunity. Many similarities and differences are reported between mouse and human DCs $[33,34]$. We found that Alternaria inhibits the DC defense mechanism for viral infections through TLR3. This conclusion is based on the following observations: Alternaria inhibited TLR3 mRNA and protein expression induced by dsRNA. Alternaria inhibited dsRNA-induced IFN- $\beta$, IP-10 and I-TAC production. By characterizing the inhibitory activities, they are likely derived from heatstable molecules, which is a MW $>100 \mathrm{kDa}$ in the case of Alternaria.

Alternaria induces calcium-dependent eosinophil degranulation, surface expression of CD63 and CD11b and 


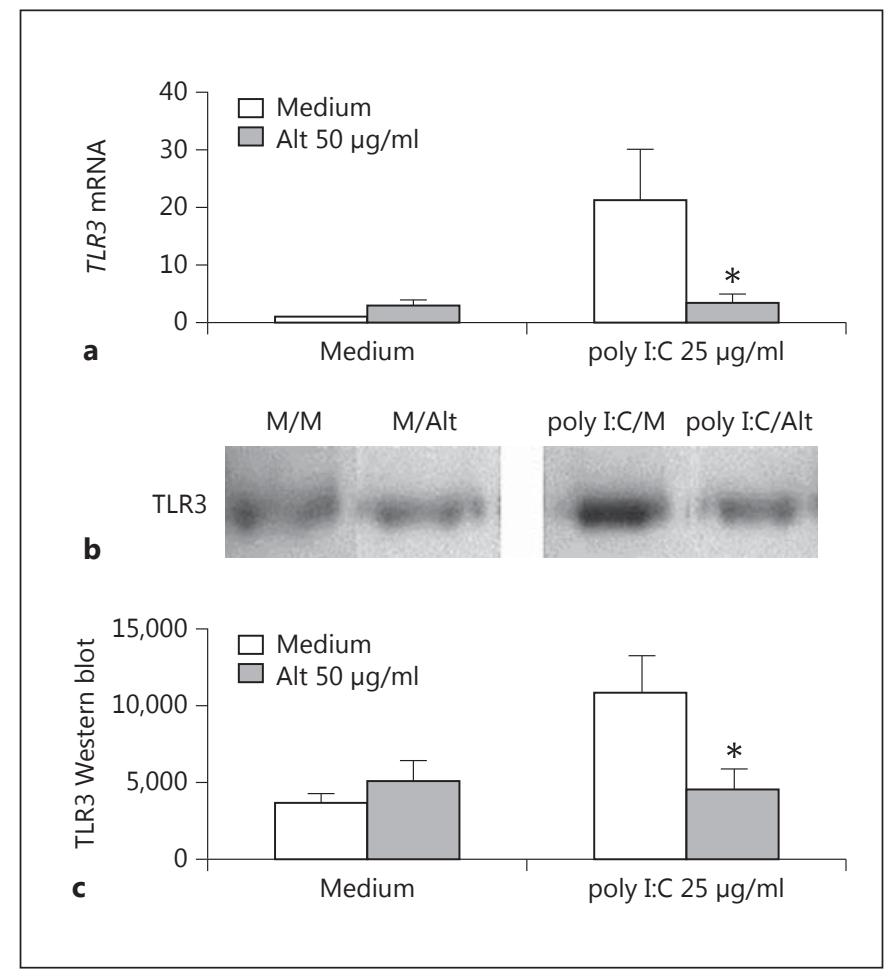

Fig. 4. Alternaria inhibits expression of TLR3 of DCs. DCs were incubated with poly I:C $(0,25 \mathrm{mg} / \mathrm{ml})$ and Alternaria $(0,50 \mu \mathrm{g} / \mathrm{ml})$. a TLR3 mRNA expression from DCs was analyzed by quantitative real-time PCR. Quantitative real-time PCR was performed using specific primer sets for TLR3 and $18 S$ rRNA. Results are mean \pm $\operatorname{SEM}(\mathrm{n}=5) .{ }^{*} \mathrm{p}<0.05$ compared with medium or poly I:C alone. b Samples were analyzed by Western blotting through the use of antibody to mouse TLR3 antibody. The figure is representative of 5 experiments showing similar results. $\mathrm{M}=$ Medium. $\mathbf{c}$ The intensities of the TLR3 bands were quantitated by densitometric analyses. Data were normalized to the values of medium alone as $100 \%$. Data are presented as means \pm SEM from 5 separate experiments. $* \mathrm{p}<0.05$ compared with medium or poly I:C alone. Alt $=$ Alternaria.

Fig. 5. Alternaria factor(s) to inhibit poly I:C-induced IP-10 production by DCs is largely heat-stable and with a MW >100 kDa. MW examinations were investigated. Alternaria extract was subjected to membrane filtration with YM100 Centricom membrane. Next, we tried to investigate the effects of temperature on Alternaria. After filtration, Alternaria extracts were exposed to 4, 37 and $56^{\circ} \mathrm{C}$ for $30 \mathrm{~min}$. Data are presented as means \pm SEM from $4 \mathrm{sep}-$ arate experiments. ${ }^{*} \mathrm{p}<0.05$ and ${ }^{* *} \mathrm{p}<0.01$ represent significant differences compared with medium/Alternaria treated at $4^{\circ} \mathrm{C}$ and poly I:C/Alternaria treated at $4^{\circ} \mathrm{C}$. Alt $=$ Alternaria .
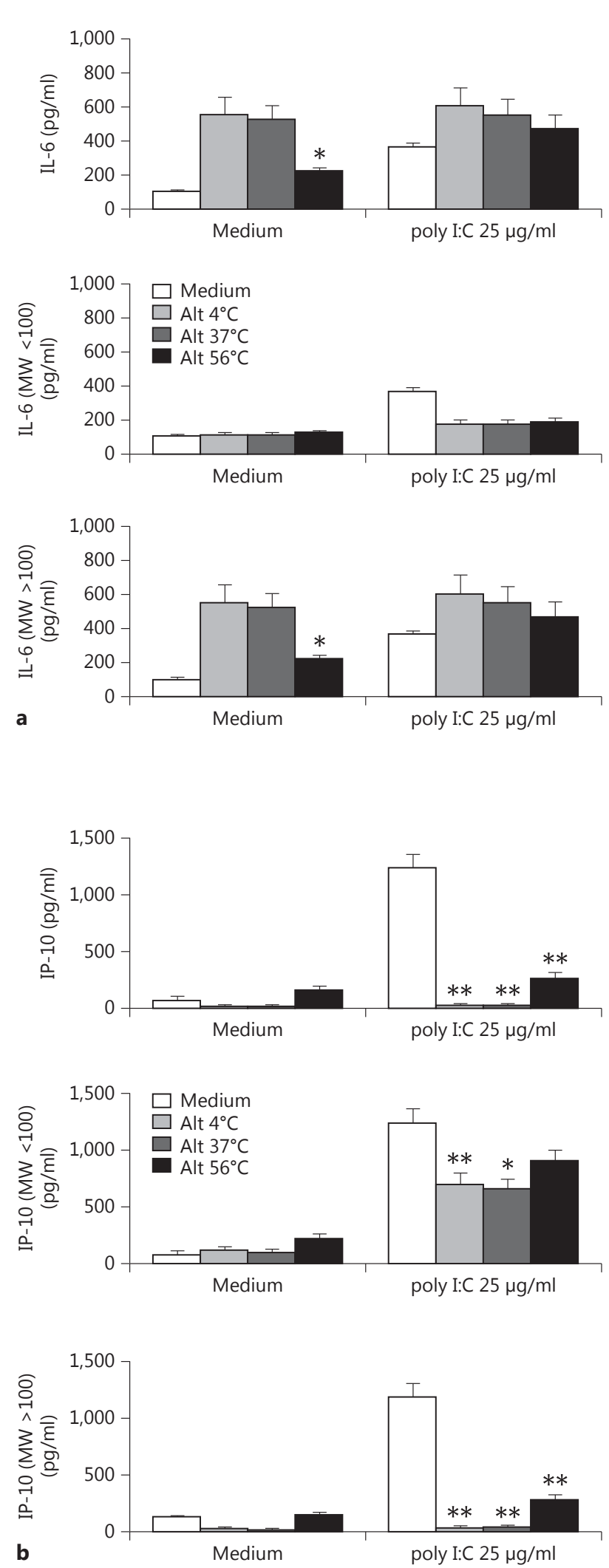

Wada/Kobayashi/Matsuwaki/Moriyama/ Kita 


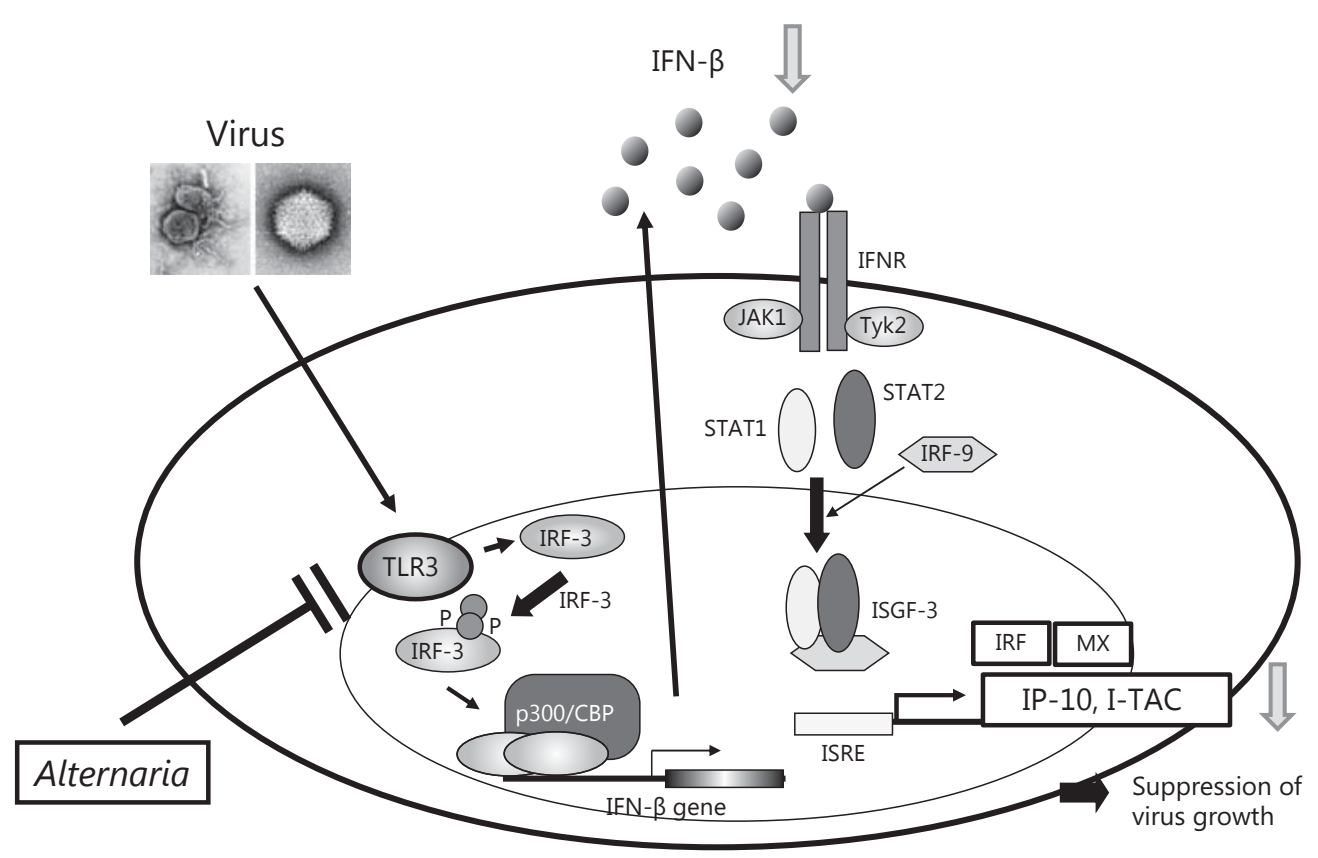

Viral infection $\rightarrow$ IRF-3 activate $\rightarrow$ IFN- $\beta \rightarrow$ IFNR, JAK, STAT activate $\rightarrow$ ISGF-3 $\rightarrow$ IP-10, I-TAC $\rightarrow$ Suppression of viral proliferation

Fig. 6. TLR3-mediated signaling pathways. TLR3 recognizes a synthetic analog of viral dsRNA, poly I:C and viral dsRNAs derived from dsRNA viruses. TLR3 signaling activates the transcription factor IRF-3. IRF-3 translocates to the nucleus, where it forms a transcriptional complex with the transcription coactivator p300/ $\mathrm{CBP}, \mathrm{NF}-\kappa \mathrm{B}$ and Jun, which subsequently binds to interferon stimulated response elements (ISRE). Secreted IFNs bind and activate the type I IFN receptor (IFNR) in an autocrine and paracrine man- ner. This binding leads to the activation of IFN-stimulated gene factor 3 (ISGF-3; a heterotrimer of STAT1, STAT2 and IRF-9), which translocates to the nucleus and induces the transcription of hundreds of effector molecules, called IFN-inducible genes. These effector molecules directly influence protein synthesis such as IP10 and I-TAC. In summary, Alternaria inhibits TLR3 expression and production of IFN- $\beta$, I-TAC and IP-10 by DCs stimulated with poly I:C. production of IL-8 [35]. Aspartate protease from Alternaria induces this eosinophil activation through protease-activated receptor (PAR)-2 [36]. This aspartate protease activity also induces IL-6, IL-8 and GM-CSF production and calcium response in airway epithelium through PAR-2 [37]. Alternaria also induces TSLP production from airway epithelial cells. IL-4 enhances Alternaria-induced TSLP production, but IFN- $\gamma$ inhibits it [38]. In addition, Alternaria induces IL-33 production and extracellular ATP release from normal human bronchial epithelial cells [39]. Kobayashi et al. [40] reported that strong Th2 responses were observed when mice were exposed to OVA in the presence of Alternaria. If mice had been exposed to OVA and Alternaria previously, the OVA challenge induced marked airway eosinophilia and significantly produced IL-13 in lung homogenates compared to mice exposed to OVA alone. When allogenic
$\mathrm{CD}^{+} \mathrm{T}$ cells from $\mathrm{B} 6$ mice incubated with Alternariastimulated BM-derived DCs from BALB/C mice, Th2 cytokines such as IL-4, IL-5 and IL-13 were significantly increased compared with nonstimulated DCs; however, they produced less IFN- $\gamma$. Thus, Alternaria potently enhances Th2-type immune responses and eosinophilic inflammation in the airways. In this study, Alternaria attenuated chemokine production by DCs, suggesting that Alternaria likely profoundly modulates host immune responses.

A question still exists regarding which factors in the Alternaria are involved in these responses. Protease activities in Alternaria play an important role in the activation of eosinophils and epithelial cells, because heat treatment over $56^{\circ} \mathrm{C}$ abolishes these activities. In our mouse DC study, carbohydrate structures, such as chitin and glycan may play pivotal roles for these reactions because 
these activities are not inactivated by heat treatment for $30 \mathrm{~min}$ at $56^{\circ} \mathrm{C}$ and are mainly induced by a MW of $>100$ molecules.

Interestingly, respiratory viral infections have been implicated in exacerbations of allergic asthma, characterized by a Th2-biased immune response [41]. Contoli et al. [42] showed deficient induction of IFN by rhinovirus in asthmatic primary bronchial epithelial cells and alveolar macrophages, which was highly correlated with the severity of rhinovirus-induced asthma exacerbation and virus load in experimentally infected human volunteers. Respiratory viruses target airway epithelial cells and DCs. Torres et al. [28] reported that intranasal administration of dsRNA in OVA-sensitized wild-type mice significantly increased airway hyperresponsiveness, lung inflammation and OVA-specific Th2 response. Reuter et al. [21] also reported that application of poly I:C induces production of allergen-specific IgE and IgG1, whereas resiquimod (R848) had no effect. Activation of TLR3 in combination with inhaled allergen results in the induction of DC activation and migration. Kobayashi et al. [40] show that the presence of Alternaria leads to Th2-like adjuvant effects. We also found that Alternaria inhibits TLR3 expression on DCs. Further studies will be necessary to elucidate the mechanism involved in inhibition of TLR3 expression by Alternaria.

In summary, our findings in this study demonstrate that Alternaria inhibits TLR3 expression and productions of IFN- $\beta$, I-TAC and IP-10 by DCs stimulated with poly I:C (fig. 6). We conclude that Alternaria inhibits the defense mechanism for viral infections. These results suggest the possibility that the presence of Alternaria exacerbates both upper and lower airway disease such as CRS and bronchial asthma.

\section{Acknowledgement}

This work was supported by the National Institutes of Health Grants AI49235 and AI71106 and the Mayo Foundation.

\section{Disclosure Statement}

The authors have no financial conflict of interest.

\section{References}

1 Moorman JE, Rudd RA, Johnson CA, King M, Minor P, Bailey C, et al: National surveillance for asthma - United States, 1980-2004. MMWR Surveill Summ 2007;56:1-54.

2 Zhu Z, Zheng T, Homer RJ, Kim, YK, Chen NY, Cohn L, Hamid Q, Elias JA: Acidic mammalian chitinase in asthmatic Th2 inflammation and IL-13 pathway activation. Science 2004;304:1678-1682.

- 3 Reese TA, Liang HE, Tager AM, Luster AD, Van Rooijen N, Voehringer D, Locksley RM: Chitin induces accumulation in tissue of innate immune cells associated with allergy. $\mathrm{Na}-$ ture 2007;447:92-96.

-4 Chupp GL, Lee CG, Jarjour N, Shim YM, Holm CT, He S, Dziura JD, Reed J, Coyle AJ, Kiener P, Cullen M, Grandsaigne M, Dombret MC, Aubier M, Pretolani M, Elias JA: A chitinase-like protein in the lung and circulation of patients with severe asthma. N Engl J 20075;357:2016-2027.

5 Denning DW, O'Driscoll BR, Hogaboam CM, Bowyer P, Niven RM: The link between fungi and severe asthma: a summary of the evidence. Eur Respir J 2006;27:615-626.

6 Solomon WR: Assessing fungus prevalence in domestic interiors. J Allergy Clin Immunol 1975;56:235-242.
7 Crain EF, Walter M, O'Connor GT, Mitchell H, Gruchalla RS, Kattan M, Malindzak GS, Enright P, Evans R 3rd, Morgan W, Stout JW: Home and allergic characteristics of children with asthma in seven US urban communities and design of an environmental intervention: the Inner-City Asthma Study. Environ Health Perspect 2002;110:939-945.

-8 Amr S, Bollinger ME, Myers M, Hamilton RG, Weiss SR, Rossman M, Osborne L, Timmins S, Kimes DS, Levine ER, Blaisdell CJ: Environmental allergens and asthma in urban elementary schools. Ann Allergy Asthma Immunol 2003;90:34-40.

-9 Forno E, Celedón JC: Predicting asthma exacerbations in children. Curr Opin Pulm Med 2012;18:63-69.

10 Jackson DJ, Johnston SL: The role of viruses in acute exacerbations of asthma. J Allergy Clin Immunol 2010;125:1178-1187.

11 Green RM, Custovic A, Sanderson G, Hunter J, Johnston SL, Woodcock A: Synergism between allergens and viruses and risk of hospital admission with asthma: case-control study. BMJ 2002;324:763.
12 Meltzer EO, Hamilos DL, Hadley JA, Lanza DC, Marple BF, Nicklas RA, Adinoff AD, Bachert C, Borish L, Chinchilli VM, Danzig MR, Ferguson BJ, Fokkens WJ, Jenkins SG, Lund VJ, Mafee MF, Naclerio RM, Pawankar R, Ponikau JU, Schubert MS, Slavin RG, Stewart MG, Togias A, Wald ER, Winther B, Rhinosinusitis Initiative: Rhinosinusitis developing guidance for clinical trials. J Allergy Clin Immunol 2006;118:S17-S61.

13 Gotfried MH: Macrolides for the treatment of chronic sinusitis, asthma, and COPD. Chest 2004;125:52S-60S.

14 Moriyama H, Ozawa M, Honda Y: Endoscopic endonasal sinus surgery. Approaches and post-operative evaluation. Rhinology 1991; 29:93-98.

15 Ponikau JU, Sherris DA, Kephart GM, Adolphson C, Kita H: The role of ubiquitous airborne fungi in chronic rhinosinusitis. Clin Rev Allergy Immunol 2006;30:187-194.

-16 Wood AJ, Antoszewska H, Fraser J, Douglas RG: Is chronic rhinosinusitis caused by persistent respiratory virus infection? Int Forum Allergy Rhinol 2011;1:95-100.

17 Gwaltney JM Jr, Phillips CD, Miller RD, Riker DK: Computed tomographic study of the common cold. N Engl J Med 1994;330:25-30. 
18 Wang J, Watanabe S, Matsukura S, Suzaki H: Double-stranded RNA poly (I:C) enhances matrix metalloproteinase mRNA expression in human nasal polyp epithelial cells. Acta Otolaryngol Suppl 2009;562:105-109.

19 Pedersen M, Sakakura Y, Winther B, Brofeldt S, Mygind N: Nasal mucociliary transport, number of ciliated cells, and beating pattern in naturally acquired common colds. Eur J Respir Dis Suppl 1983;128:355-365.

-20 Rock FL, Hardiman G, Timans JC, Kastelein RA, Bazan JF: A family of human receptors structurally related to Drosophila Toll. Proc Natl Acad Sci USA 1998;95:588-593.

21 Reuter S, Dehzad N, Martin H, Böhm L, Becker M, Buhl R, Stassen M, Taube C: TLR3 but not TLR7/8 ligand induces allergic sensitization to inhaled allergen. J Immunol 2012; 188:5123-5131.

22 Reynolds HY: Modulating airway defenses against microbes. Curr Opin Pulm Med 2002; 8:154-165.

23 Gordon S: Pattern recognition receptors: doubling up for the innate immune response. Cell 2002;111:927-930.

-24 Alexopoulou L, Holt AC, Medzhitov R, Flavell RA: Recognition of double-stranded RNA and activation of NF-kappaB by Tolllike receptor 3. Nature 2001;413:732-738.

25 Atmar RL, Guy E, Guntupalli KK, Zimmerman JL, Bandi VD, Baxter BD, Greenberg SB: Respiratory tract viral infections in inner-city asthmatic adults. Arch Intern Med 1998;58 2453-2459.

-26 Doyle SE, O'Connell R, Vaidya SA, Chow EK, Yee K, Cheng G: Toll-like receptor 3 mediates a more potent antiviral response than Tolllike receptor 4. J Immunol 2003;170:35653571.

27 Jiang Z, Zamanian-Daryoush M, Nie H, Silva AM, Williams BR, Li X: Poly (I-C)-induced Toll-like receptor 3 (TLR3)-mediated activation of NFkappa B and MAP kinase is through an interleukin-1 receptor-associated kinase (IRAK)-independent pathway employing the signaling components TLR3-TRAF6-TAK1TAB2-PKR. J Biol Chem 2003;278:1671316719.
28 Torres D, Dieudonné A, Ryffel B, Vilain E, SiTahar M, Pichavant M, Lassalle P, Trottein F, Gosset P: Double-stranded RNA exacerbates pulmonary allergic reaction through TLR3: implication of airway epithelium and dendritic cells. J Immunol 2010:185:451-459.

29 Honda K, Takaoka A, Taniguchi T: Immunity. Type I interferon [corrected] gene induction by the interferon regulatory factor family of transcription factors. Immunity 2006;25: 349-360.

30 Uematsu S, Akira S: Toll-like receptors and type I interferons. J Biol Chem 2007;282: 15319-15323.

31 Inaba K, Inaba M, Romani N, Aya H, Deguchi M, Ikehara S, Muramatsu S, Steinman RM: Generation of large numbers of dendritic cells from mouse bone marrow cultures supplemented with granulocyte/macrophage colony-stimulating factor. J Exp Med 1992;176: 1693-1702.

32 Radhakrishnan S, Nguyen LT, Ciric B, Ure DR, Zhou B, Tamada K, Dong H, Tseng SY, Shin T, Pardoll DM, Chen L, Kyle RA, Rodriguez M, Pease LR: Naturally occurring human IgM antibody that binds B7-DC and potentiates $\mathrm{T}$ cell stimulation by dendritic cells. J Immunol 2003;170:1830-1838.

33 Villadangos JA, Shortman K: Found in translation: the human equivalent of mouse CD8+ dendritic cells. J Exp Med 2010;207:11311134 .

34 Robbins SH, Walzer T, Dembélé D, Thibault C, Defays A, Bessou G, Xu H, Vivier E, Sellars M, Pierre P, Sharp FR, Chan S, Kastner P, Dalod M: Novel insights into the relationships between dendritic cell subsets in human and mouse revealed by genome-wide expression profiling. Genome Biol 2008;9:R17.

35 Inoue Y, Matsuwaki Y, Shin SH, Ponikau JU, Kita H: Nonpathogenic, environmental fungi induce activation and degranulation of human eosinophils. J Immunol 2005;175:54395447.
6 Matsuwaki Y, Wada K, White TA, Benson LM, Charlesworth MC, Checkel JL, Inoue Y, Hotta K, Ponikau JU, Lawrence CB, Kita H: Recognition of fungal protease activities induces cellular activation and eosinophil-derived neurotoxin release in human eosinophils. J Immunol 2009;183:6708-6716.

37 Matsuwaki Y, Wada K, White T, Moriyama $\mathrm{H}$, Kita $\mathrm{H}$ : Alternaria fungus induces the production of GM-CSF, interleukin-6 and interleukin- 8 and calcium signaling in human airway epithelium through protease-activated receptor 2. Int Arch Allergy Immunol 2012; 158:19-29.

38 Kouzaki H, O’Grady SM, Lawrence CB, Kita $\mathrm{H}$ : Proteases induce production of thymic stromal lymphopoietin by airway epithelial cells through protease-activated receptor-2. J Immunol 2009; 183:1427-1434.

-39 Kouzaki H, Iijima K, Kobayashi T, O’Grady SM, Kita $\mathrm{H}$ : The danger signal, extracellular ATP, is a sensor for an airborne allergen and triggers IL-33 release and innate Th2-type responses. J Immunol 2011;186:4375-4387.

40 Kobayashi T, Iijima K, Radhakrishnan S, Mehta V, Vassallo R, Lawrence CB, Cyong JC, Pease LR, Oguchi K, Kita H: Asthma-related environmental fungus, Alternaria, activates dendritic cells and produces potent Th2 adjuvant activity. J Immunol 2009; 182:25022510.

41 Dahl ME, Dabbagh K, Liggitt D, Kim S, Lewis DB: Viral-induced T helper type 1 responses enhance allergic disease by effects on lung dendritic cells. Nat Immunol 2004;5:337343.

42 Contoli M, Message SD, Laza-Stanca V, Edwards MR, Wark PA, Bartlett NW, Kebadze T, Mallia P, Stanciu LA, Parker HL, Slater L, Lewis-Antes A, Kon OM, Holgate ST, Davies DE, Kotenko SV, Papi A, Johnston SL: Role of deficient type III interferon-lambda production in asthma exacerbations. Nat Med 2006; 12:1023-1026. 